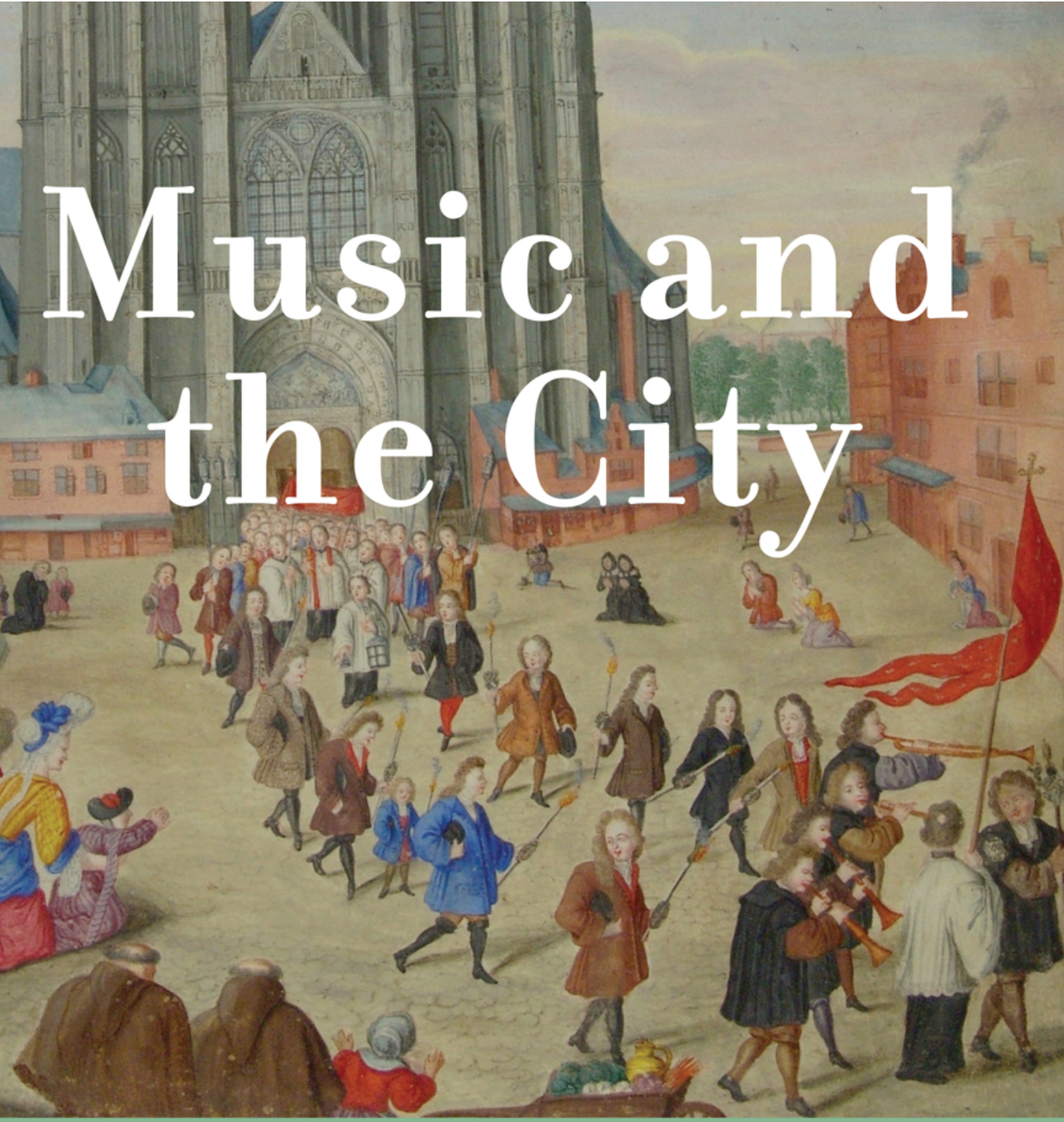

Musical Cultures and Urban Societies in the Southern Netherlands and Beyond, c. $1650-1800$

Stefanie Beghein, Bruno Blondé \& Eugeen Schreurs (eds) 


\section{Music and the City}

Musical Cultures and Urban Societies in the Southern Netherlands and Beyond, c. 1650-1800

Edited by

Stefanie BegheIN, Bruno Blondé \& Eugeen Schreurs 
(C) 2013 by Leuven University Press / Presses Universitaires de Louvain / Universitaire Pers Leuven. Minderbroedersstraat 4, B-3000 Leuven (Belgium).

All rights reserved. Except in those cases expressly determined by law, no part of this publication may be multiplied, saved in an automated datafile or made public in any way whatsoever without the express prior written consent of the publishers.

ISBN 9789058679550

D / 2013 / 1869 / 57

NUR: 694

Cover design: Stephanie Specht

Cover illustration: Title page, Gulden Boek van de Broederschap van de XIV-daagse berechting, Kathedraalarchief Antwerp. Courtesy of Karel Moens

(Museum Vleeshuis | Klank van de Stad).

Layout: Frederik Danko

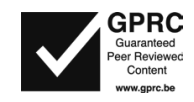

4 


\title{
Apollo's gifts. Dutch songbooks for the urban youth of the eighteenth century
}

\author{
LOUIS P. GRIJP
}

Meertens Institute - Utrecht University

This article aims to contribute to our knowledge of informal urban singing culture in the Netherlands, especially within the context of youth subcultures. Hundreds of songbooks from the period of the Dutch Republic (the seventeenth and eighteenth centuries) evidence such a singing culture. ${ }^{1}$ Young men used to give songbooks as presents to their girlfriends. Pictures show young men and their girlfriends singing together from such songbooks, with or without the accompaniment of a lute or other instrument. In other instances the songs were sung by groups of young people during trips outside the city. ${ }^{2}$

For the seventeenth century this singing culture has been studied in some detail. Interesting sources are the so-called local songbooks with titles such as Amsterdamse minnezuchjes (Amsterdam love sighs, 1643) and Haerlemse duyn-vreught (Haarlem dune delight, 1636). The title engravings depict the local youth enjoying themselves in the vicinity of their town, boating on the river or walking through the greenwoods or dunes -singing from the songbook in question. ${ }^{3}$ Did they continue doing so in the eighteenth century? For this period songbooks and informal singing culture have been much less studied, but generally speaking the singing culture of the preceding century seems to have continued in many respects. In the eighteenth century there were local songbooks as well, although these were devoted to smaller towns than in the seventeenth, and the books became cheaper.

In the eighteenth century two types of secular songbooks enjoyed enormous popularity: the mopsjes and the minnewitten. Mopsjes refer to a complex of local songbooks in the north of the province of Holland, the earliest copies of which

\footnotetext{
${ }^{1}$ For a survey see Daniel F. ScheurleER, Nederlandse liedboeken. Lijst der in Nederland tot het jaar 1800 uitgegeven liedboeken, The Hague, 1908 (Supplement 1923, reprint 1977). Many of the songs and songbooks are accessible at www.liederenbank.nl (Nederlandse Liederenbank or Dutch Song Database of the Meertens Institute, Amsterdam).

${ }^{2}$ See e.g. Natascha Veldhorst, Zingend door het leven. Het Nederlandse liedboek in de Gouden Eeuw, Amsterdam, 2009; Natascha VELDHORST, "Pharmacy for the body and soul. Dutch songbooks in the seventeenth century", in Early music history, 27, 2008, pp. 217-286.

${ }^{3}$ Louis P. GRIJP, “De Rotterdamse faem-bazuyn. De lokale dimensie van liedboeken uit de Gouden Eeuw”, in Volkskundig bulletin, 18, 1992, pp. 23-78. Digital version at www.dbnl.nl.
} 
date from the middle of the seventeenth century. These songbooks were reprinted, enlarged and combined until well into the eighteenth century, with titles such as 't Groot Hoorns, Enkhuyzer, Alkmaarder en Purmerender liede-boek (Big Hoorn, Enkhuizen, Alkmaar, and Purmerend songbook). In the eighteenth century they were no longer published in their original towns, but rather in Amsterdam. Despite their titles the books were not large, printed as they were in $32 \mathrm{mo}(4.5 \times 7 \mathrm{~cm})$, so that girls could easily carry them in their handbags. It is said that during West-Frisian wedding parties the mopsjes were presented to guests on silver dishes. The mopsjes were massproduced items, and dozens of editions have been preserved. ${ }^{4}$

The minnewitten were similarly popular. Their official title was Thirsis minnewit (Goal of Thirsis's love), the first edition of which was published in Amsterdam in 1708. Soon the book grew to three parts, which were reprinted dozens of times during the first half of the eighteenth century. The minnewitten consisted mainly of love songs. As with the mopsjes most of the minnewit songs are contrafacta, i.e. song texts written to pre-existing tunes - which already in the seventeenth century was the dominant system. ${ }^{6}$ Unfortunately, the minnewitten do not tell us much about their intended singers and use.

\section{Overview of Apollo's gifts and the annual feasts involved}

In this article I will focus on a lesser known complex of popular secular songbooks from the middle of the eighteenth century, which will be referred to as Apollo's gifts. ${ }^{7}$ The principal question will be what they can tell us about the singing culture of young urban people. What role did these songbooks play in their leisure activities?

We will begin with a copy of Apollo's gifts owned by the Meertens Institute in Amsterdam. It is a collection of five songbooks in octavo, bound together. The volume begins with Apollos Kermis-gift (Apollo's Kermesse gift, referring to the fair) in two parts, followed by a New Year gift, a St. Nicholas gift and a Vastenavondsgift - that is, Shrove Tuesday gift or Carnival (or Mardi Gras) gift. ${ }^{8}$ Although some of the books are reprints, the volume reflects more or less the chronology of the series, which began with the Kermesse gift printed by Jan van den Bergh

\footnotetext{
${ }^{4}$ GRIJP, "De Rotterdamse faem-bazuyn", p. 33 and pp. 54-55. The songbooks are called "mopsjes" because they contain songs sung by a shepherd called Mopsus.

${ }^{5}$ Marga Kuijpers and Jos Houtsma are preparing an edition of the first part of Thirsis minnewit.

${ }^{6}$ Louis P. GRIjP, Het Nederlandse lied in de Gouden Eeuw. Het mechanisme van de contrafactuur, Amsterdam, 1991. Digital version at www.dbnl.nl.

${ }^{7}$ For this article I gratefully made use of Erik BosGRAAF's excellent Apollo's giften. Een serie wereldijke liedboeken uit het midden van de achttiende eeuw, unpublished master's thesis, Utrecht University, 2006. Digital version at http://igiturarchive.library.uu.nl.

${ }^{8}$ Meertens Institute, inv. no. 3978 Gesloten Kast B66: (1) Apollo's Kermis-gift. Eerste deel, Dordrecht: Hendrik Walpot, s.d.; (2) Apollo's Kermis-gift, tweede deel, Dordrecht: Hendrik Walpot, s.d.; (3) Apollo's Nieuwe-Jaers-gift. Aen het bekoorlyke Hollandsche jufferschap, The Hague: Jan van den Bergh, 1745; (4) Apollo's St. Nicolaas gift, aan Minerva, Leiden: Johannes van Kerckhem, probably 1742; (5) Apollo's Vastenavond-gift, Dordrecht: Hendrik Walpot, s.d. These five books are accessible via the Dutch Song Database at www.liederenbank.nl.
} 
1740 in The Hague and continued until at least 1753, including reprints in Amsterdam, Leiden, Dordrecht, Hoorn, and Rotterdam. Not included in the Meertens volume are a third part of the Kermesse gift (1746) and a second part of the New Year gift (1753), which bring the total number of songbooks to seven. They contain over 600 song texts but offer no music notation, only references to tunes. All songs are anonymous, as are the collectors.

Here is an overview of the first editions of Apollo's gifts, the core of the complex, in chronological order:

\begin{tabular}{|c|c|c|}
\hline 1740 & Apollo's Kermesse gift I & The Hague: Jan van den Bergh \\
\hline$[1741]$ & Apollo's St. Nicholas gift & Leiden: Johannes van Kerckhem \\
\hline 1742 & Apollo's New Year gift & The Hague: Jan van den Bergh \\
\hline 1743 & Apollo's Kermesse gift II & The Hague: Jan van den Bergh \\
\hline 1745 & Apollo's Carnival gift & The Hague: Pieter Servaas \\
\hline 1746 & Apollo's Kermesse gift III & Amsterdam: Jacobus Friesewyck \\
\hline 1753 & Apollo's New Year gift II & Rotterdam: Hendrik Maronier \\
\hline
\end{tabular}

Before going into detail on the rather complicated publishing history of these books (a survey of which is given in the Appendix), I will look at them from a functional perspective.

\section{Apollo's Kermesse gift}

The intended recipients of the first book of the Apollo series become clear from the full title: "Apollo's Kermesse gift to the pleasure-minded youth of The Hague" (1740). We can see the singers in the beautiful title engraving (Illustration 1). The accompanying poem explains that Apollo, the god of Poetry, is sitting in Venus's chariot, which is drawn by two swans and driven by Cupid, and that he is distributing songs among the youth of The Hague. Note that in the engraving the songs are represented by slips of paper. Clearly, this is a pictorial means of expressing the idea of individual "songs". Visible in the upper-right corner is Bacchus, stimulating Love and Poetry.

The reprint of 1743 has a new title engraving, signed by I.D. Martini (Illustration 2 ). This was inspired by the 1740 engraving, but now the young ladies and gentlemen are differently arranged. The book in which the individual songs were collected is seen in the hands of a young lady: she is singing from the book, accompanied by a gallant lord playing the violin. Two young men in the foreground are receiving the songs from Apollo. In the background other young people are dancing. All this is explicitly mentioned in the poem: the youngsters and nymphs (as the girls are called) are urged to sing about the sweetness of love, and others are called to dance merrily to the sound of the singing and strings.

One aspect of the engraving that is interesting for our investigation is not mentioned in the poem: the young people's clothing - the men in redingotes, wearing three-cornered hats, and the women in silk robes - suggests that they belong to the 
upper classes. This seems to be confirmed in the preliminaries, where the dedicatees of Apollo's Kermesse gift are addressed as "MeJuffers" (My Ladies, p. 7) and the buyers as "Myn Heeren" (My Lords, p. 14). From the preliminaries of one of the songbooks we learn that the book was not inexpensive: 14 to 16 styvers (pennies) apiece, although reprints were a few styvers cheaper, as is noted with some disdain. ${ }^{9}$ This is confirmed by advertisements. The Hague printer Jan van den Bergh sold bound copies of the first edition of the Kermesse gift for 16 styvers; the Rotterdam bookseller Maronier asked 10 styvers for a reprint. A copy of the Carnival gift cost just 8 styvers. ${ }^{10}$ However, typical cheap songbooks, affordable for the common people, cost about 3 styvers. ${ }^{11}$

Possibly by suggesting the upper class as the intended public the publishers took advantage of the penchant of the middle class to imitate the habits of Lords and Ladies. According to Justus van Effen's moral weekly Hollandsche Spectator, on Sundays tailors, surgeons, shopkeepers, and clockmakers dressed themselves like Lords, except for the swords, and addressed each other as "Myn Heer" (on weekdays they said "Mossie", a familiar abbreviation of "Monsieur"). ${ }^{12}$ Note that in the title engravings of the Kermesse gift some of the young lords are carrying a sword (Illustrations 1-3).

The preliminaries also inform us about the purpose of the songs:

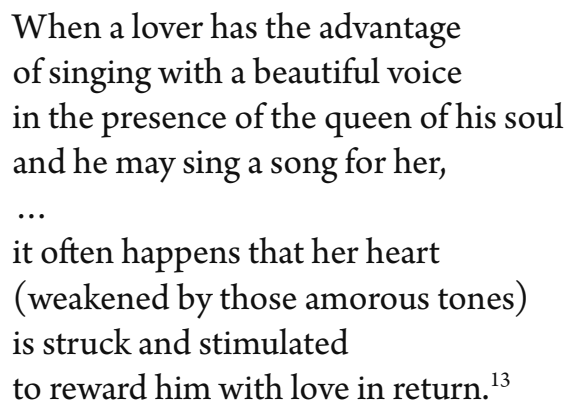

\footnotetext{
${ }^{9}$ Apollo's Nieuwe-Jaers-gift, 1745, Opdracht, p. 6.

${ }^{10}$ Jan van den Bergh advertised Apollo's Kermis-gift for 16 styvers in Leidsche Courant, 1 January 1742. Hendrik Maronier advertised both parts of Apollo's Kermis-gift à 10 styvers each in 's-Gravenhaagse Courant, 1 January 1753; Pieter Servaes advertised Apollo's Vasten-avond-gift for 8 styvers in 's-Gravenhaagse Courant, 26 February 1745 and 4 May 1749.

${ }^{11}$ Three styvers was the most common price for songbooks in the first half of the seventeenth century, according to Louis P. Grijp, "Voer voor zanggrage kropjes. Wie zongen uit de liedboekjes uit de Gouden Eeuw?", in Bladeren in andermans hoofd. Over lezers en leescultuur, ed. Theo BIJvoET et al., Nijmegen 1996, pp. 96-125, at pp. 100-102. A hundred and fifty years later, we still find similar prices in e.g. Den groten zee-held Paul Jonas, Amsterdam, 1782 (2 styvers, mentioned in dedicaton 'to the singers') and De schreeuwende Katsoe, Amsterdam: Erve Vander Putte, c. 1775 (4 styvers, mentioned on title page).

${ }^{12}$ Justus van EfFEN, De Hollandsche Spectator, Aflevering 233 (14 December 1733), ed. José DE KRUIF, Leuth, 2001, pp. 251-252.

13 "Wanneer een minnaar 't voordeel heeft / Van met fraye stem te zingen, / In 't byzyn van zyn Zielvorstin / En haar een deuntje voor mag kwelen, / (...) / Gebeurd dikwils, dat haar hert / (Verzagt door die verliefde toonen) / Geraakt en aangedreven werd, / Om hem met wedermin te loonen.” Apollo's Kermis-gift II, Voorbericht aan den Leezer, fol. A4 (copy Meertens Institute).
} 


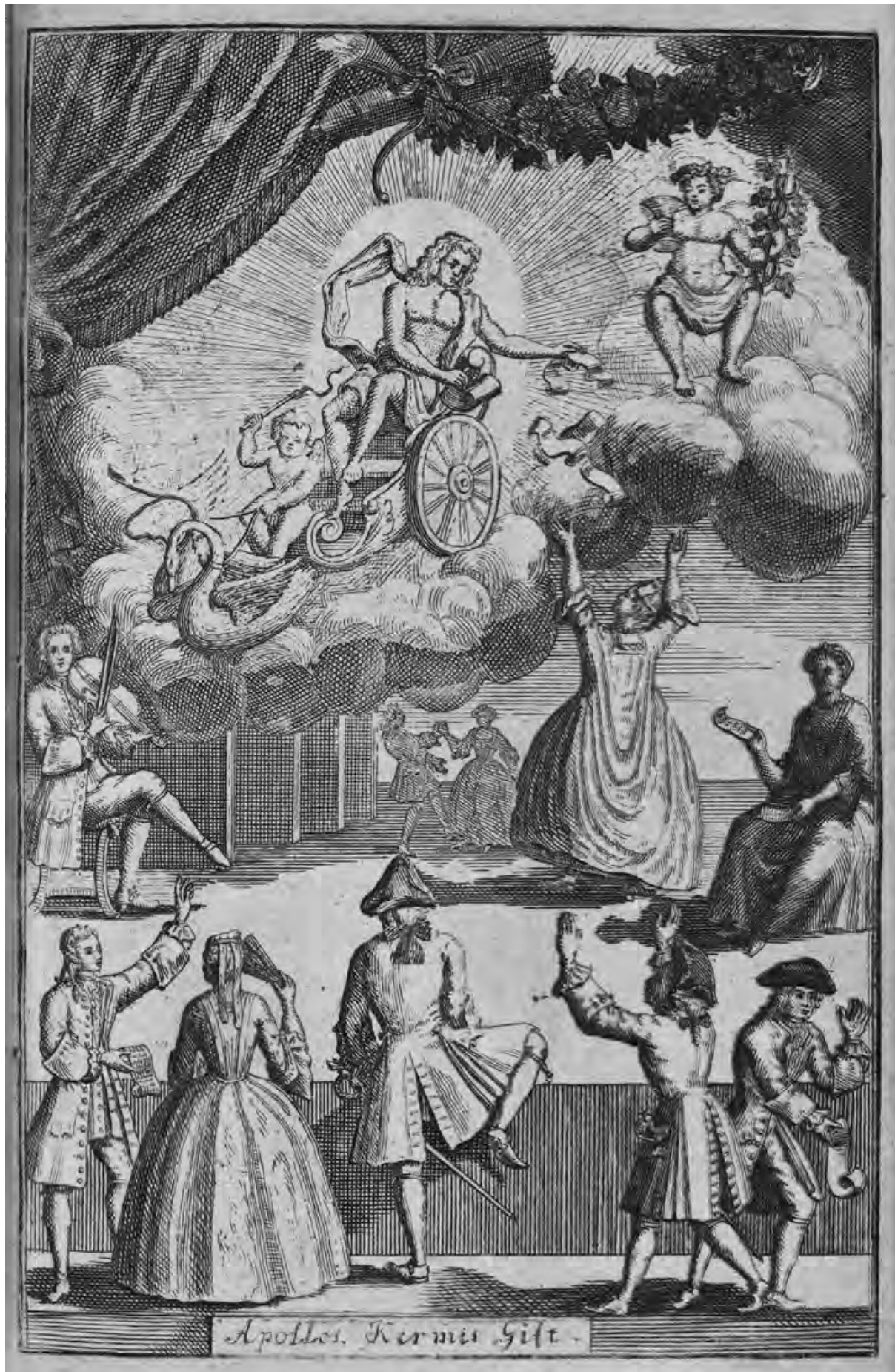

Illustration 1. Apollo's Kermis-gift, part 1. The Hague: Jan van den Bergh, 1740. Anonymous title engraving. The Hague, National Library, 5 D 2 [1]. 


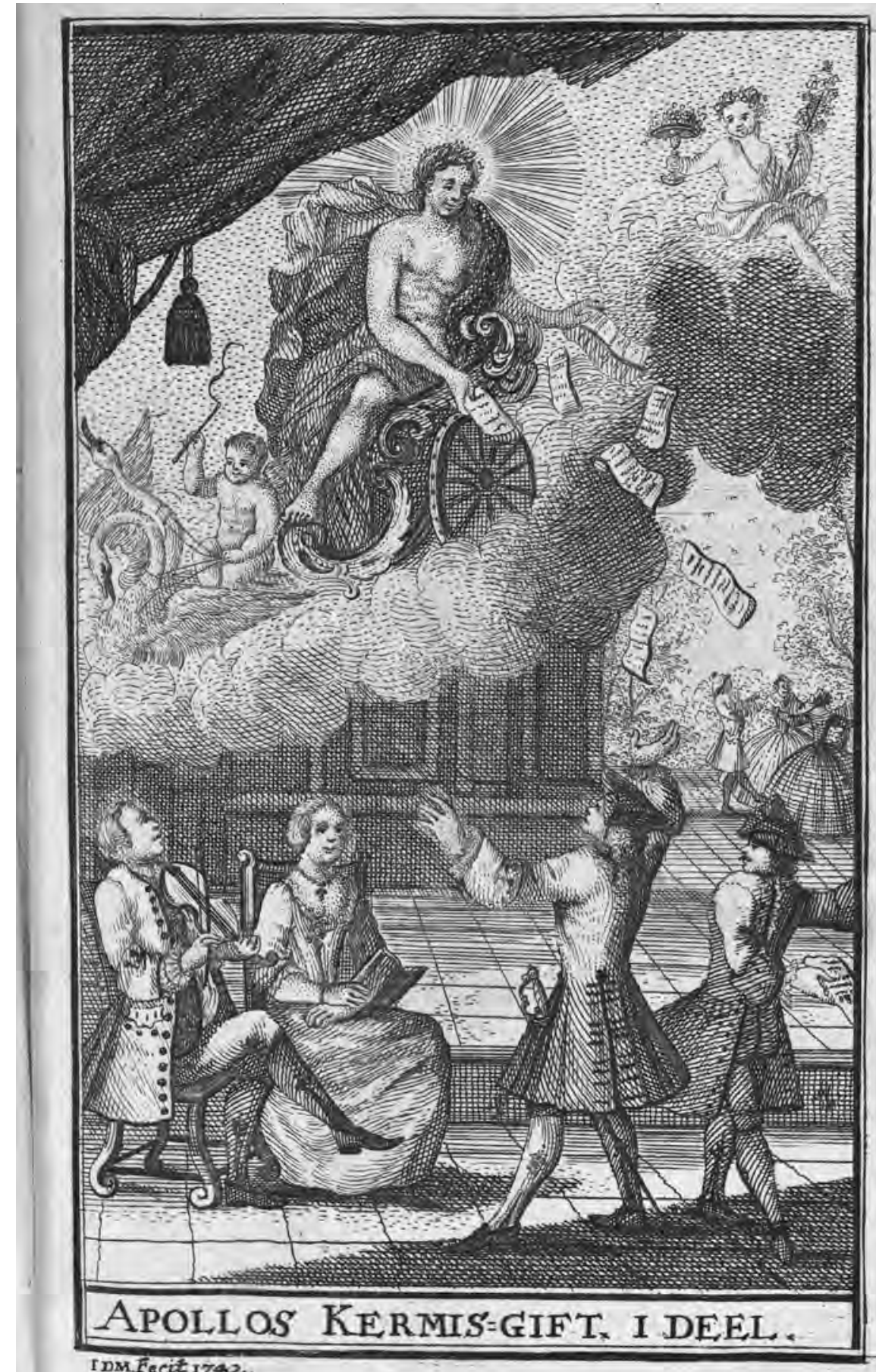

IDM.Feciti792,

Illustration 2. Apollo's Kermis-gift, part 1, second edition. The Hague: Jan van den Bergh, 1743. Title engraving by IDM (I.D. Martini), dated 1742. The Hague, National Library, 5 D 4 [1a]. 


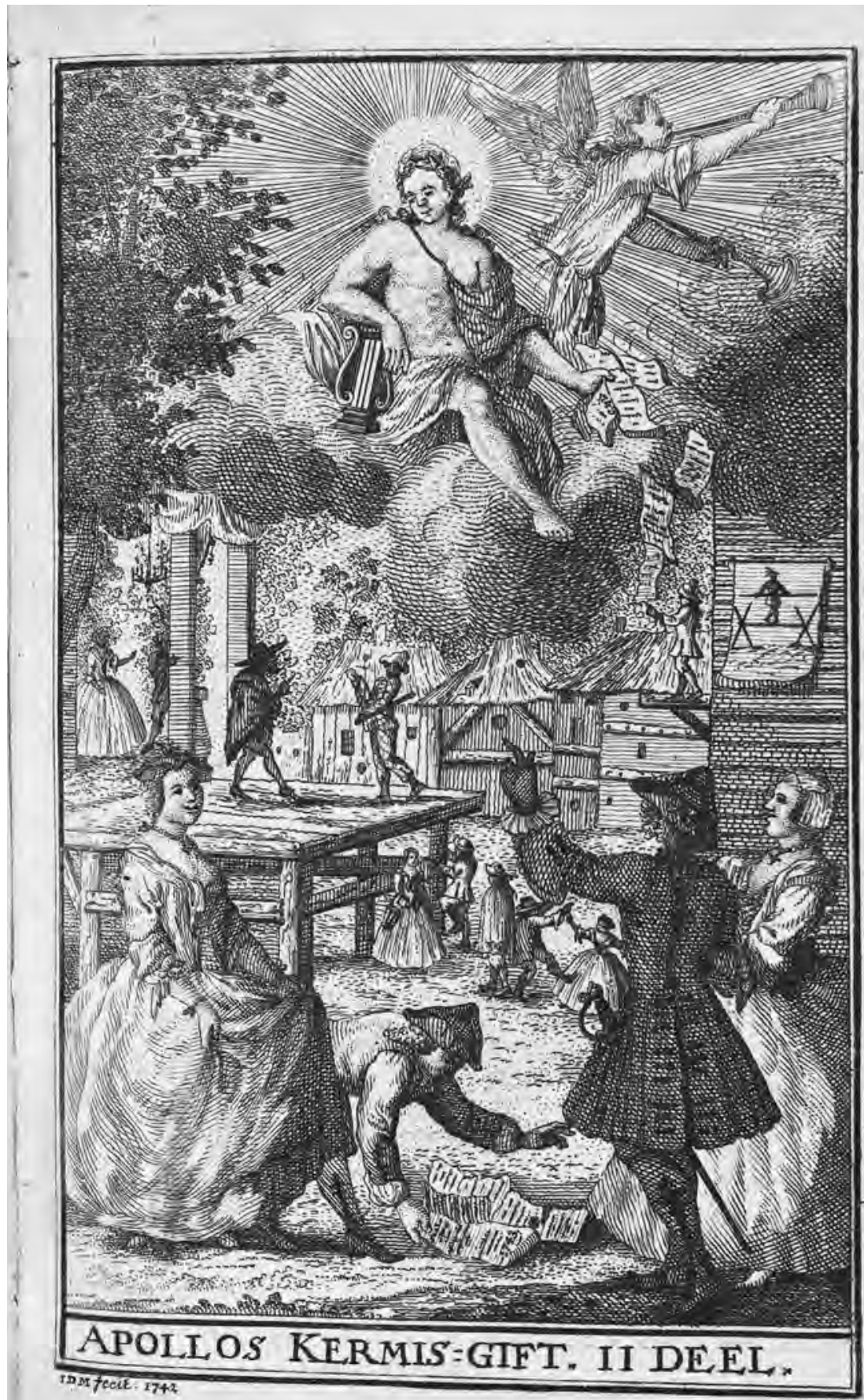

Illustration 3. Apollo's Kermis-gift, part 2. The Hague: Jan van den Bergh, 1743. Title engraving by IDM (I.D. Martini), dated 1742 and (on one of the song sheets in the representation) 1743. The Hague, National Library, 5 D 2 [2]. 
But it was not just the suitors who sang; the spinsters did likewise, of course. In a dedication to the Juffers (Ladies) this is formulated as follows:

We ... request ... if we have the good fortune to enjoy your company, that you will entertain us with an air from the songbook. Because nothing has more power over the heart of young lords than the soul-delighting voice of a beautiful young lady. ${ }^{14}$

We are later informed that the young lords bought copies of Apollo's Kermesse gift "to show their respect for the fair sex". ${ }^{15}$ Many of them had felt obliged to buy a Kermesse gift because of its flattering dedication to the young ladies of The Hague. This sounds as if the lords gave the songbook to their mistresses as a present, a tradition that can be traced back to the early seventeenth century. ${ }^{16}$ In fact, there had been a custom of giving presents at Kermesse time. For instance employers granted their employees a gratuity, and parents gave their children money to spend at the Kermesse. A traditional Kermesse present was a kermiskoek, a richly decorated honey cake. Young men in particular gave their girlfriends Kermesse cakes as a sign of affection. There was even a song, "Och Jan, koop mij een kermis" - "Jan, buy me a Kermesse”, i.e. a Kermesse cake. In short, giving a copy of Apollo's Kermesse gift to one's girlfriend may have fitted into a tradition of giving presents on the occasion of the Kermesse.

Another question is whether the books were in fact used at the Kermesse. This would seem to have been quite possible, too, although the books were undoubtedly also used on other occasions. People went to the Kermesse as couples or in groups of friends. In early modern times, singing was a typical activity for such merry companies. The title engraving of the second part of Apollo's Kermesse gift illustrates this (Illustration 3). Two wealthy (as indicated by their dress) young couples visiting the Kermesse eagerly receive new songs from Apollo. That such people indeed sang at the Kermesse can be deduced from the preliminaries, as we will see later. This title engraving may provoke the question whether upper-class people (or middle-class people in upper-class dress) really visited the Kermesse, with its vulgar attractions such as farces and tightrope walking. But the Kermesse was not merely cheap amusement, especially in The Hague, where the May Fair was famous for the expensive products on sale. Because the Kermesse took place early in the season, the merchants could still offer large and expensive selections. ${ }^{17}$

The Kermesse was visited not just by the common people - even stadtholders were

\footnotetext{
${ }^{14}$ Apollo's Nieuwe-Jaers-gift, Opdracht, p. 12.

${ }^{15}$ Apollo's Nieuwe-Jaers-gift, Opdracht, p. 6.

${ }^{16}$ Karel Porteman \& Mieke B. SMITs-Veldt, Een nieuw vaderland voor de muzen. Geschiedenis van de nederlandse literatuur 1560-1700, Amsterdam, 2008, p. 180.

${ }^{17}$ [Petrus Loosjes Az.], Vaderlandse historie (... $22 e$ deel (...) ten onmiddelijken vervolge van Wagenaar's Vaderlandsche historie, Amsterdam: Johannes Allart, 1740 (second print), p. 450. In September there was another Kermesse in the city. The May Fair was also called Court Fair, because only in May were the Binnenhof and Buitenhof used for the Kermesse. For a detailed description of the Hague Kermesse in the seventeenth century see Adriaen van de Venne, Tafereel van de belacchende werelt, ed. Marc Van Vaeck, Ghent, 1994, p. 646ff.
} 
fond of it. After stadtholder William III of Orange became King of England, he lived in London, but he soon became homesick. In May 1689 he realized that it was Kermesse in The Hague and wished that he could fly back like a bird through the air. ${ }^{18}$ A painting from 1781 by Hendrik Pothoven shows a most civilized Kermesse at the Buitenhof, part of the court of the stadtholder (Illustration 4). Stadtholder William V and his family can be seen near the stall to the left of centre. ${ }^{19}$

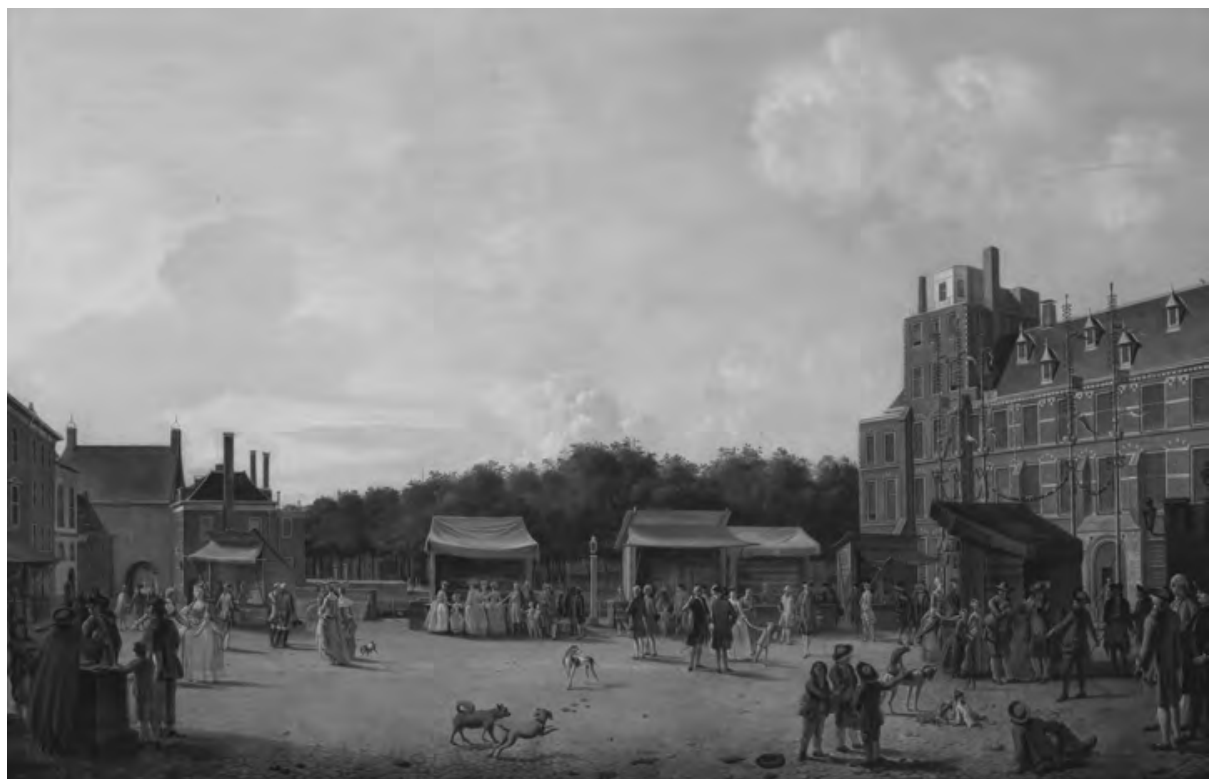

Illustration 4. Hendrik Pothoven, Kermesse at Buitenhof in The Hague (1781). The Hague, Haags Historisch Museum.

\section{Apollo's New Year gift}

In the preliminaries to Apollo's first Kermesse gift the compiler announces a similar songbook, to be entitled New Year gift. A book with that title was indeed published in 1742, less than two years after the First Kermesse gift, which had sold very well. The title engraving (by I. Schawberg or Schauberg ${ }^{20}$ is once again explained in a poem. In order to fulfill his promise, we are informed, Phoebus Apollo gives his New Year gift to "Zangkonst" (a personification of the Art of Singing, or Music), and she accepts it (Illustration 5). The young people around her represent "de onderscheyden Driften en stoffen, in dit kleen Bestek verhandelt" (the emotions and subjects of the songs

\footnotetext{
${ }^{18}$ Wout Troost, Stadhouder-koning Willem III. Een politieke biografie, Hilversum, 2001, p. 213.

${ }^{19}$ Charles Dumas, Haagse stadsgezichten 1550-1800. Topografische schilderijen van het Haags Historisch Museum, Zwolle, 1991, p. 586.

${ }^{20}$ Both readings occur in the literature. The engraver is probably Jean Henri van Schawberg (Antwerp 17171760).
} 
LOUIS P. GRIJP



Illustration 5. Apollo's Nieuwe-Jaers-gift. The Hague: Jan van den Bergh, 1742. Title engraving by I. Schawberg (or Schauberg). The Hague, National Library, 5 D 4 [2]. 
dealt with in this little book). We recognize a shepherd, a drinker, a desperate man pulling his hair out, a smoking man and a couple of lovers; these figures may personify, respectively, pastoral songs, drinking songs, love laments, tobacco and love songs. The peddler in the centre is probably referring to the selling of New Year songs. At the left, with his sieve, is Momus, the mythological critic, seeking flaws in the poems.

What did people do on New Year's Day? They went out to wish their friends and acquaintances a happy New Year, to have a drink, and to exchange presents. Employers received New Year wishes from their employees and from poor people, and in exchange gave them some money, food, or a drink. Also the youth practised the nieuwjaarslopen, going from door to door with much noise. ${ }^{21}$ In the eighteenth century, the old tradition of singing New Year songs was still alive. One might also write a song or poem as a New Year gift, often with amorous undertones. In short, it must have been a good idea to give your beloved a songbook as a New Year gift.

Apollo's St. Nicholas gift

Apollo's St. Nicolaas-gift aan Minerva (Apollo's St. Nicholas gift to Minerva), as the full title runs, was published in Leiden by Johannes van Kerckhem almost simultaneously with Apollo's New Year gift (as we will see later). The curious title engraving shows Apollo presenting his gift to Minerva, the Roman goddess of Wisdom, with St. Nicholas and Cupid as spectators (Illustration 6). In the background we see Mount Parnassus and Apollo's winged horse, Pegasus, as well as a view of the city of Leiden, in which we recognize the medieval castle (Burcht) and the Academy Building, with its characteristic tower. This is a reference to Leiden University, and the inclusion of Minerva suggests that we may situate the book in the academic milieu of the city.

Traditionally, St. Nicholas was a feast during which parents gave presents to their children, who believed that these presents were brought by the Saint riding his horse over the roofs - as children still believe today. In the eighteenth century married people also gave each other presents, such as cakes. Special St. Nicholas markets were organized, for instance in Amsterdam, and shopkeepers advertised that their shops would remain open, beautifully illuminated, until nine o'clock in the evening or even later. The fair continued the next day, not only in Amsterdam but also in cities such as 's-Hertogenbosch and Brussels. ${ }^{22}$ Advertisements in Amsterdam and Haarlem newspapers from the second half of the eighteenth century recommend books as St. Nicholas gifts.

The marriageable youth also gave each other presents. However, spinsters no longer wanted toys or dolls; now they wanted suitors. St. Nicholas was regarded as a marriage broker, and favourite presents included cake dolls in the shape of a suitor and marzipan hearts. St. Nicholas used to be an occasion for the youth to make merry and even to make love - many a girl became pregnant on St. Nicholas' Eve. It was a day when the rules could temporarily be broken, at least in the eyes of the youth.

\footnotetext{
${ }^{21}$ Eveline Doelman, Gelukkig Nieuwjaar, Amsterdam, 2010, pp. 12-13.

${ }^{22}$ Jan TER Gouw, De volksvermaken, Haarlem, 1871, p. 257.
} 


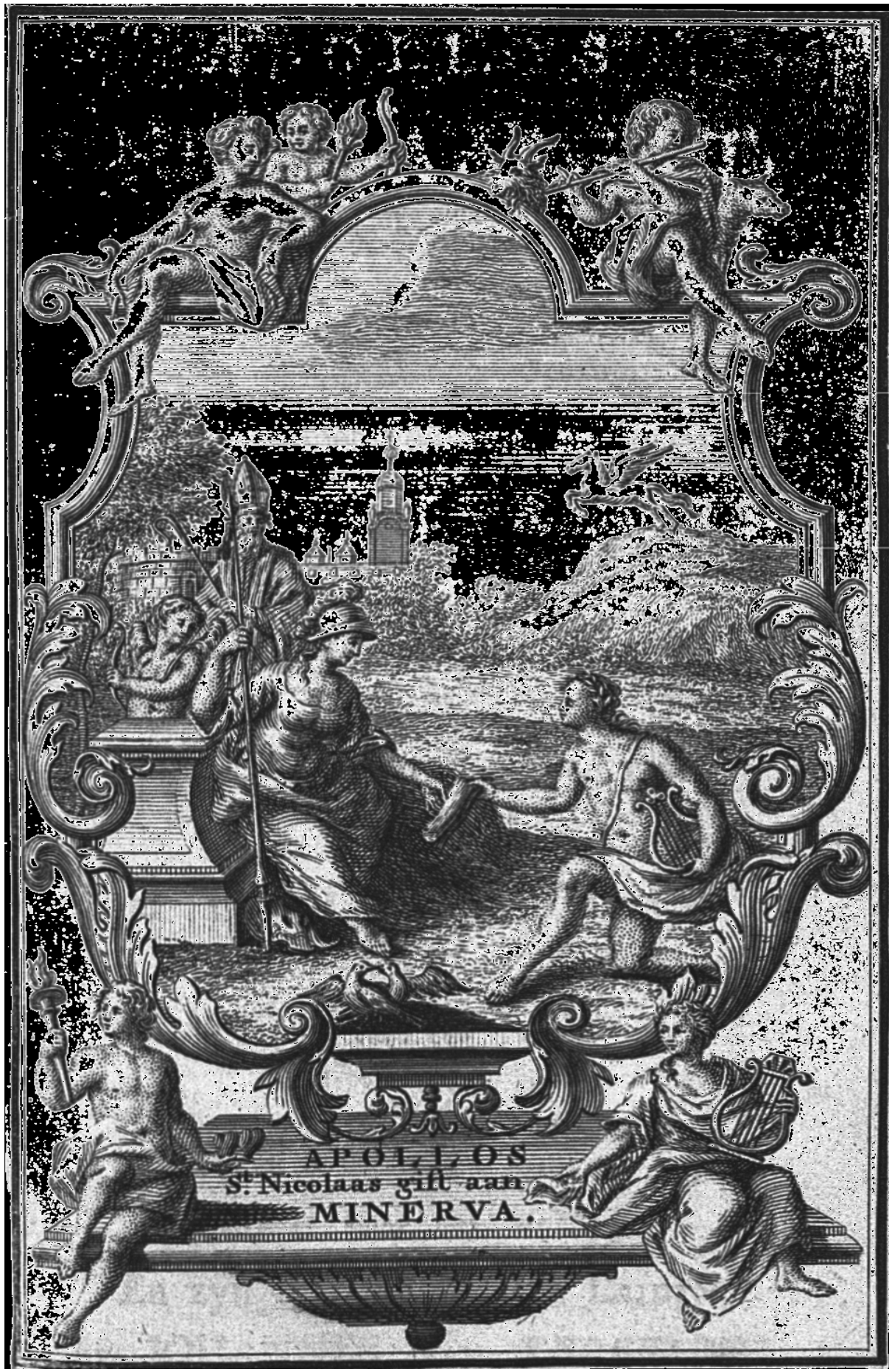

Illustration 6. Apollo's St. Nicolaas gift. Leiden: Johannes van Kerckhem, [1741]. Anonymous title engrav-

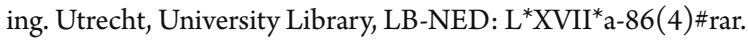


An important source of our knowledge of these customs is song texts. One such text is found in the third section of Apollo's St. Nicholas gift, containing miscellanea (Mengelzangen). This section has its own title: De verliefde student of de nieuwe zalet jonker (The amorous student or new dandy). ${ }^{23}$ There is also a title engraving (Illustration 7), which shows the student and his girlfriend; they are in a wealthy environment, with dancers and the refined music of two violins, a traverso and a spinet. The engraving does not refer to St. Nicholas, but the first song of this section does: "Sinterklaas-vreugd" (St. Nicholas' pleasure), to be sung to the tune of "Komt zoen malkaar" ("Come, kiss each other"), an intimation to us of the pleasures to be observed on St. Nicholas Day. The song describes the market stalls with all their sweet delicacies and dolls for sale; children offering hay and water to St. Nicholas's horse, expecting presents in return; and young men going into town with their girlfriends, each in order to buy his beloved a present, such as a hairpin, needle, sweet cake, or jewelry - hoping that she will give him something in return, maybe a ring or her stocking, for him to fill with more presents, to cement the friendship. The stocking may have had a sexual connotation, as appears clearly in the penultimate stanza:

Who gives a really good St. Nicholas present

makes the girls happy;

many of them remember that

nine months later.

I know girls in town

who at St. Nicholas gave

their most precious treasure,

their virginity, to a lad. ${ }^{24}$

How does all this correspond to the world of the saletjonker and his elegant girlfriend? The song seems to reveal rather more about general St. Nicholas customs of the middle or lower classes than of the upper class. However, giving a songbook to one's girlfriend as a St. Nicholas present appears to have been perfectly possible, even in higher social circles.

\footnotetext{
${ }^{23}$ For the effeminate type of the saletjonker or petit maitre see Dorothée STURKENBOom, Spectators van hartstocht. Sekse en emotionele cultuur in de achttiende eeuw, Hilversum, 1998, p. 147ff.

24 “Die wakker Zinter-Klaas goed geeft, / Die doet de Meysjes deugt, / Den tyd van negen Maanden heeft / Het menig een geheugt, / Ik weet hier Meysjes in de Stad, / Die gaven zo men zegt, / Op Zinter-Klaas haar waardste schad, / Haar Maagdom aan een Knegt.” Apollo's St. Nicolaas gift, Mengel-zangen, p. 7 (copy of Meertens Institute).
} 


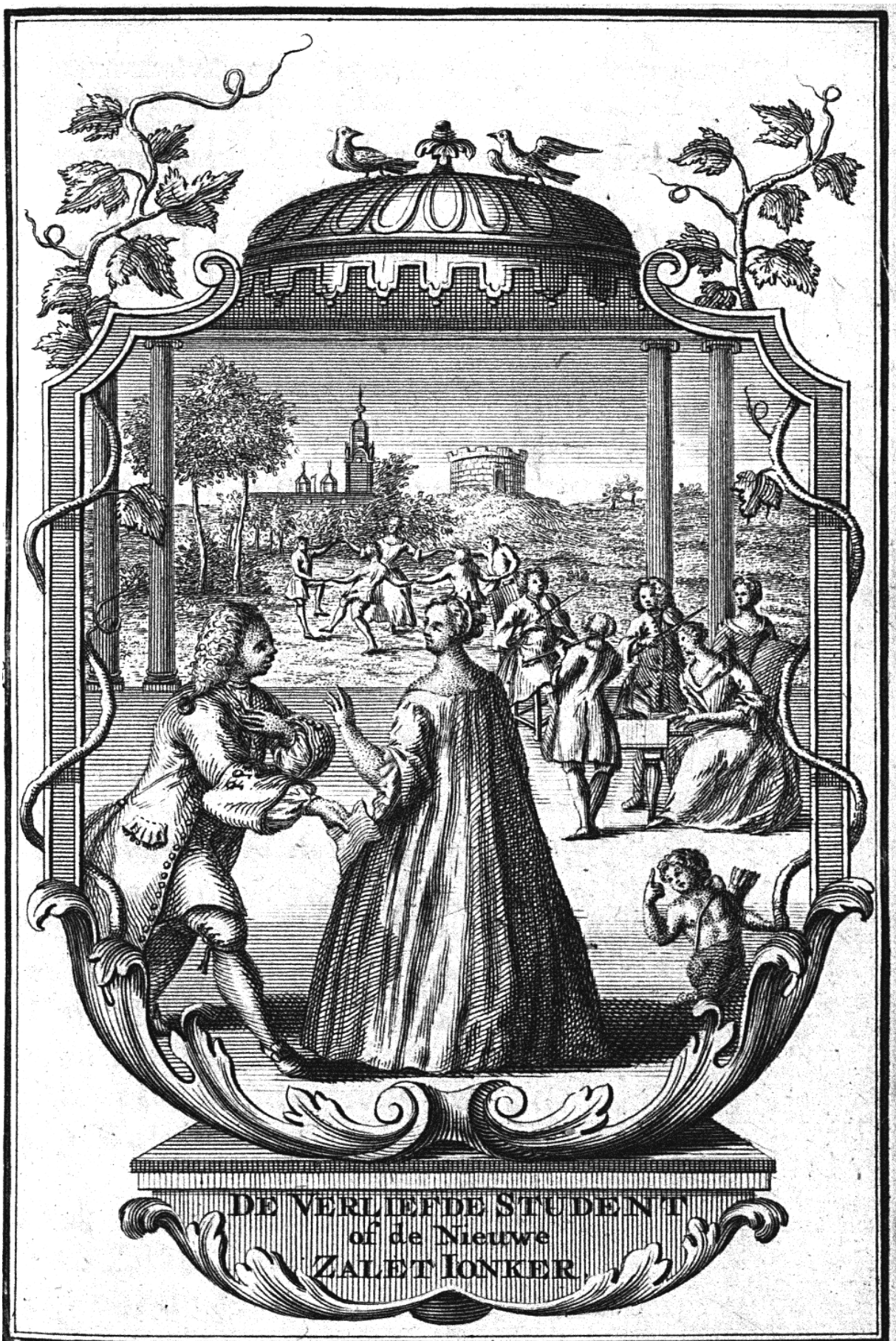

Illustration 7. Apollo's St. Nicolaas gift, section 3: Mengelzangen, or De verliefde student of de nieuwe zalet jonker, Leiden: Johannes van Kerckhem, [1741]. Anonymous title engraving. Utrecht, University Library, LB-NED: L*XVII*a-86(4)\#rar. 
Apollo's Carnival gift

The last title in the series is Apollo's Vastenavond-gift - for Shrove Tuesday or Carnival (Mardi Gras), published in The Hague by Pieter Servaas in 1745. The frontispiece shows a group of fools (as they are labelled in the explanatory poem) celebrating Carnival with dance and music (Illustration 8). This was again a feast during which the youth went out in groups, with much singing and ample opportunity for drinking and lovemaking (although one wonders about the extent to which such behaviour was allowed in eighteenth-century Calvinist The Hague). But could Carnival also serve as an opportunity for the giving of a songbook as a present? In other words, did people give presents at Carnival? I could find no evidence for this from either historical or ethnological sources. The only parallel I came across was websites that sold Carnival presents like beer belts, string thing limbos, and Mr. Bean teddy bears - funny items which might be useful when celebrating Carnival. ${ }^{25}$ Such websites offer myriad kinds of presents, all categorized for different purposes, and clearly the sellers have had the idea of mentioning Carnival as an additional opportunity for giving gifts. Perhaps the publisher Servaas had the same idea in 1745 when looking for another feast to elaborate on so as to exploit the successful concept of the songbook as a gift for an annual feast.

To conclude this point: what made the Kermesse, New Year, St. Nicholas and Carnival appropriate occasions for giving songbooks as presents? These four feasts had common features, including some relevant rituals:

1. They were (outdoor) festivities which people attended in groups. This was true for the Kermesse and Carnival, and probably for the eighteenth-century St. Nicholas markets/fairs and for New Year's Day.

2. The feasts served as opportunities for meeting potential marriage partners.

3. On these occasions singing was important. Many Kermesse, New Year, St. Nicholas and Carnival songs have been preserved. They were sung by the merry celebrators and by children going from door to door, asking for money or sweets.

4. Presents were given at St. Nicholas, of course, but also at New Year and the Kermesse; Carnival is an exception in this respect.

Thus, the feasts were important events for the young. No doubt, during the festivities they sang songs they had learnt from songbooks and broadsheets, and probably from Apollo's gifts as well.

So far little has been noted about the content of the songbook complex, which holds a body of over 600 song texts. The main focus is love: love songs and complaints, dialogues, shepherds' songs, farewell and wedding songs; and, as a curious continuation of the wedding context, a song on the occasion of visiting a new mother and her baby, and some lullabies. There are also drinking songs and ballads about romantic occasions and comical events.

Remarkably few songs are about the feasts referred to in the titles of the books. In this respect the St. Nicholas Pleasure song cited previously is rather exceptional. In the whole

\footnotetext{
${ }^{25}$ A beer belt can hold six or more cans or bottles of beer around one's waist. A string thing limbo is an electric music machine that shoots out a colorful string that dancers have to pass beneath leaning back their body.
} 


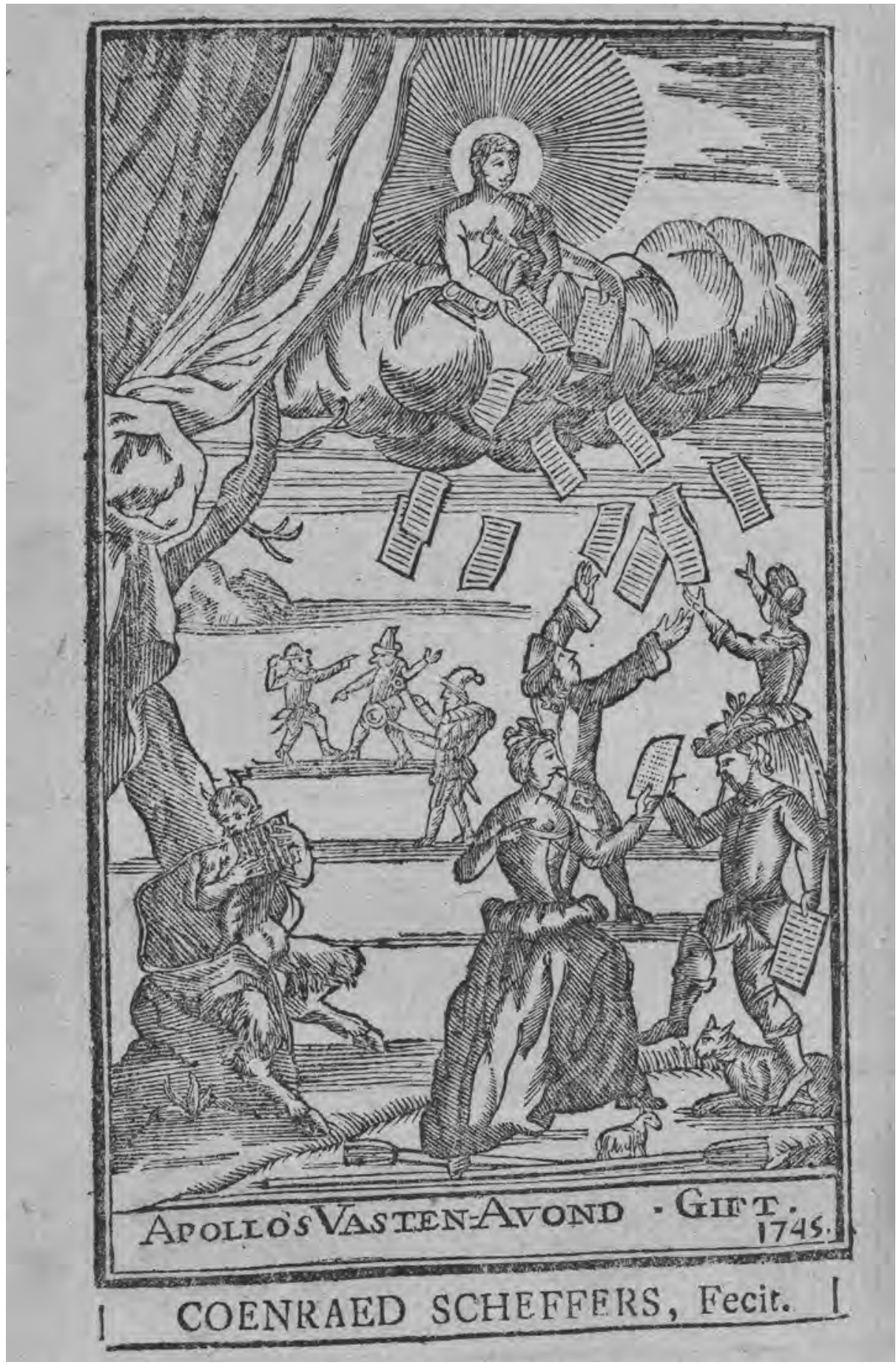

Illustration 8. Apollo's Vasten-avond-gift. Frontispiece, woodcut by Coenraed Scheffers. The Hague: Pieter Servaas, 1745. The Hague, National Library, 5 D 9 [2]. 
body of work there are just two other songs referring to St. Nicholas. One is a St. Nicholas poem (intended to be sung) accompanying a present, printed in the First Kermesse gift; the other is about a young man who dreams that St. Nicholas brings him a spinster. ${ }^{26}$

In the whole of Apollo's gifts there are five songs about the Kermesse. One song offers a vivid description of the Amsterdam fair, including a quack doctor, lusty drunken girls who become pregnant, and East Indian men spending their money in the company of prostitutes. ${ }^{27}$

There are no traditional New Year songs in the corpus, although two songs were written as "New Year gifts". Social satire such as in the St. Nicholas Pleasure and the Amsterdam Kermesse song is found in a lament about the innumerable people who come to the door on New Year's Day, such as rubbish collectors, watchmen with their rattles, barbers, poor orphans, New Year singers, drummers, lice catchers and a hondenslager (dog beater), followed by people with bills to be paid. ${ }^{28}$ Surprisingly, there are no carnival songs in the corpus, despite the rich tradition of this genre.

\section{Genesis of Apollo's gifts}

After this general overview of the Gift complex and its possible function in the Dutch youth culture of the eighteenth century, we will examine the circumstances in which the songbooks came into being. From what is noted in the preliminaries we can reconstruct the genesis to some extent. The person who in 1740 took the initiative for the Kermesse gift, and thus for the whole series, was a long-winded man, who signed his dedication of the Gift with the letter D. ${ }^{29} \mathrm{He}$ collected songs written by others and participated in the youth activities; he and the Hague young ladies to whom he dedicated the songbook knew each other personally. At weddings, people complained to him that there were not enough new songs available, and at private parties he himself noted that only straatdeunen (vulgar street songs or broadside ballads) were sung. Moreover, when somebody happened to sing a good new song, the singer was unwilling to write it down or lend it to anyone. Nevertheless, by this time D. had succeeded in collecting a number of songs, all (to the best of his knowledge) new, which he had now given to the printer. Thus $\mathrm{D}$. could give the songbooks to the Hague youth as "Apollo". If the printer made a profit, there were plans for a subsequent volume, a New Year gift, for which readers were asked to send in new songs.

D.s dedication is followed by a rhymed preface, signed by R.D.N. (who may or may not be the same person), which tells us that the song texts were written over

\footnotetext{
26 "Sint Nicolaas-deuntje aan Gloris met een zuiker ventje en wyfje”, Kermesse gift I, p. 69; “Sint Nicolaes deuntje”, New Year gift I, p. 87.

27 “Een vermakelyk Kermis-lied”, St. Nicholas gift, 3rd part, p. 31.

28 "Nieuwejaers zang”, New Year gift I, p. 114.

${ }^{29}$ It is not clear whether 'D.' is an initial. In the text the author is addressed as 'Meester J.... BosgraAf, Apollo's Giften, p. 7 suggests that 'D.' stands for 'Dienaer' (Servant).
} 
a period of about three years by three young men who used to sing together or in the company of their girlfriends. They wrote sad songs in times of adversity, when someone's girlfriend had to leave, when a relationship ended, and when someone had been rejected. However, in times of amorous prosperity they wrote songs in praise of their Cloris or Climene, as well as drinking and comical songs.

When it became clear that sales of the Kermesse gift were good, preparations for a New Year gift were started. In his Dedication to the Dutch Young Ladies, the editor of this Gift, who signs himself as "R.E.W.", calls himself a friend of the editor of the Kermesse gift. He has received the songs from a woman, whom he calls Thalye, i.e. Thalia, and introduces as having been the leader of the Muses. After having sung through her texts the editor corrected them and asked his valet to take them on horseback to The Hague. There, on St. Nicholas' Feast (5 December), the valet handed the manuscript to the printer [Jan van den Bergh], who managed to have the book ready on New Year's Day 1642.

In the dedication of the New Year gift another songbook is mentioned: Apollo's St. Nicholas gift. The editor had heard that the latter work would be published in Leiden with a hostile preface stating that many songs in the Kermesse gift were taken from older songbooks. This was a serious accusation, because it was an important selling point for the Kermesse Gift that all its songs were new.

In fact, Apollo's St. Nicholas gift was published by the Leiden printer Johannes van Kerkhem. Despite the rumour about its preface, the Dedication, signed by an unidentified K.V.I., does not explicitly mention the Gifts from The Hague; K.V.I. merely notes that he has received songs from St. Nicholas in order to have them printed "just before New Year". Obviously, he wanted this work to come before the New Year gift. ${ }^{30}$ That he succeeded in his endeavour becomes clear from the epilogue to a later edition of the New Year gift, in which it is recounted that on New Year's Day 1642 "Apollo" distributed the New Year gifts to Thalia and her girlfriends, on which occasion they also became acquainted with a copy of St. Nicholas gift. ${ }^{31}$ Thalia in particular mocked the Leiden songbook and the dedication to the serious Minerva, which seemed most inappropriate to her. Finally, Apollo threw the "bastard gift" into the "Pool of Oblivion".

The Third Kermesse gift (1746) was dedicated not to the Hague but to the Amsterdam girls. In the Dedication we are informed that "Febus" (i.e. "Apollo", the man we know as "D.") had begun his Kermesse gifts after hearing girls singing inferior street songs at the Hague Kermesse. During a recent visit to the Amsterdam Kermesse, Apollo had been surprised to learn that Amsterdam girls knew and sang songs from his Kermesse

\footnotetext{
${ }^{30}$ That there was a race is confirmed by an advertisement by the Hague printer Jan van den Bergh for his New Year Gift in the Leidsche Courant of 1 January 1742.

${ }^{31}$ Apollo's Nieuwe-Jaars-gift, Dordrecht: Hendrik Walpot, 1750, fol. H5ff. From all this we may deduce that the undated St. Nicholas gift was published in the final days of 1741. Up until now this book had been dated c. 1730, following SCHEuRleER, Nederlandse liedboeken, p. 204. The epilogue, called Kundschap van Parnassus (Message from Parnassus), is signed by "Bokkalini", which would refer to the Italian satirist Trajano Boccalini (1556-1613), author of the famous Ragguagli di Parnaso (News-sheet from Parnassus), 1612.
} 
gifts. Consequently, he gave a manuscript of songs to an unnamed Amsterdam printer in order to have them published. ${ }^{32}$ Thalia played a role in the genesis of this collection too. She found the songs in a curious spot: they had been sewn into the petticoat of one of her "sisters", who had fainted. After having unstitched them Thalia gave the songs to Apollo, who approved them and in turn gave them to the girls, saying that they should learn them by heart and sing no others. On this occasion he promised the publication of a third Kermesse gift, which eventually took place in Amsterdam. ${ }^{33}$

From all this we may conclude that the Kermesse gift and New Year gift were rooted in a group of young people in The Hague who enjoyed singing at parties and feasts. They probably belonged to the upper class, as suggested by the valet and the horse of the editor of the New Year gift. How old were they? The ages of two of the Hague girls are mentioned in anniversary songs: they became eighteen and twenty years old, respectively. ${ }^{34}$ We may assume that the members of the group were unmarried, at least initially, as in the six-year period between the First Kermesse gift and Third Kermesse gift the marital status of most of them would have changed. The wedding songs and lullabies in the songbooks may illustrate that shift.

Usually, in the early modern period it was mainly men who made, collected and published songs; the role of women was only to sing, preferably from memory. However, Apollo's gifts seem to have been different in this respect. The woman called Thalia may have been the writer of the songs of the New Year gift. It is typical of the gender relations of the time that the editor of the New Year gift corrected Thalia's songs - women were considered to have difficulties with spelling. The role of the girl who fainted is unclear. If we take Thalia's story literally, the girl is the compiler or writer of the songs of the Third Kermesse gift; another possibility is that Thalia simply invented the story and collected or wrote the songs herself. Only in case of the First and Second Kermesse gifts we are told that the songs were written by men. ${ }^{35}$

Apollo's Carnival gift, published in 1745 by Pieter Servaas, seems to have been produced outside the youth circle described above. In the preliminaries there is no reference to anyone of this circle and the somewhat rude woodcut title by Coenraed Scheffers (Illustration 8) suggests that the Carnival gift was a cheaper imitation of the other books. Sure enough, it cost half the price of the First Kermesse Gift, as we have seen before.

\footnotetext{
${ }^{32}$ In fact, the Third Kermesse gift was published by Jacobus Friesewyck in Amsterdam, in 1746.

${ }^{33}$ It is remarkable that "Apollo" did not have his Third Kermesse gift published in The Hague by Jan van den Bergh, who printed the first Kermesse gift (1740) including a reprint in 1743, the New Year gift (1742) including a reprint in 1745, and the second Kermesse gift (1743). Van den Bergh was active in the period 1739-1748 (STCN).

34 “Verjaarsang aan dezelve. Twintig jaaren oud zynde”, Apollo's Kermisgift I, p. 49, following "Verjaarsang aan Amira”. "O meisje in wiens jaren men drie sesjes telt" (so 3x6=18 years old), Apollo's Vastenavond-gift, p. 59.

${ }^{35}$ The First Kermesse gift was written by three young men, as stated before. In the dedication of the Second Kermesse gift the editor "D" apologises to the "Gentlemen authors" for belittling their work ("Heeren Autheurs, verschoont nu dat ik uw werk een weynig declineer”, p. 8).
} 


\section{Musical language choice}

What may seem to contradict the suggestion of Apollo's gifts's upper-class roots is that nearly all the songs are in Dutch. After all, in eighteenth-century Holland there was a process of Frenchification at work. French dress fashion was imitated and more and more French words found their way into the vernacular. Of course, the French influence also affected music, including informal singing. As early as in the seventeenth century many tunes for Dutch song texts originated from France. But did the Dutch also sing the French songs in French? Song manuscripts may evidence the use of French song texts, as manuscripts generally reflect actual singing practices better than do printed songbooks. We know many such song manuscripts from the seventeenth- and eighteenth-century Southern Netherlands which contain many French songs; ${ }^{36}$ unfortunately, this type of source has not yet been systematically studied for the Northern Netherlands. ${ }^{37}$ However, in Holland French songs would have been sung, especially by the upper classes. In Van Effen's moral weekly Hollandsche Spectator of 14 December 1733 we read about the middle classes imitating the upper classes in this respect, although the former spoke French less well, due to their spending fewer years in French schools. According to Van Effen's middle-class correspondent, middle-class people sometimes made language mistakes when singing French songs. He states that the upper classes usually followed foreign musical fashions immediately, whereas the middle classes might be five or six fashions behind with their French songs - precisely because they learnt their songs from the upper classes. ${ }^{38}$

This suggests that French songs were sung where we would expect most of the buyers of Apollo's gifts to have been. However, printed songbooks show few traces of this practice. As a rule, in the eighteenth century they were monolingual or almost monolingual - some collections contain one or two French songs. Apollo's Kermesse gift contains no French songs; the New Year gift includes songs in which French and Dutch alternate. Apollo's Carnival gift contains two serious French songs, interestingly enough with Dutch tune indications. Considerably more French songs can be found in the songbook Hollandszen Praat-vaars Nieuwjaarsgift (Dutch Chatterbox's New Year gift), which should be dated a few years after Apollo's New Year gift (see below). Dutch Chatterbox's New Year gift contains seventeen French songs, many of them with Dutch titles and tune indications, along with songs in German and Latin. Obviously, it was the compiler's choice whether he followed the literary custom and selected just songs in the vernacular, or whether he compiled a heterogeneous collection that reflected the singing customs of the target group.

\footnotetext{
${ }^{36}$ Pieter Moelans, Handgeschreven liederen. Wereldijke liedcultuur in liedhandschriften (Zuidelijke Nederlanden, ca. 1600-ca. 1800) uit de Gentse universiteitsbibliotheek, unpublished doctoral thesis, Leuven University, 2009.

${ }^{37}$ In the Dutch Song Database I came across several relevant song manuscripts: [Handschrift drink- en minneliedjes, Hollands en Frans], c. 1710-1750: The Hague, National Library, MS 133 K 37, with Dutch and French songs; and Rommel sootje (Hotch-Potch), mid-eighteenth century: The Hague, National Library, MS Doedens, with 113 French, 15 Dutch and 3 German songs; [Liedboek met Ned. en Franse liederen met wijsaanduidingen], c. 1750: Leeuwarden, Provinciale Bibliotheek, MS 1421, with Dutch and at least one French song.

${ }^{38}$ VAn EfFen, De Hollandsche Spectator, Aflevering 233 (14 December 1733), ed. José DE KRUIF, Leuth, 2001, pp. 256-257.
} 


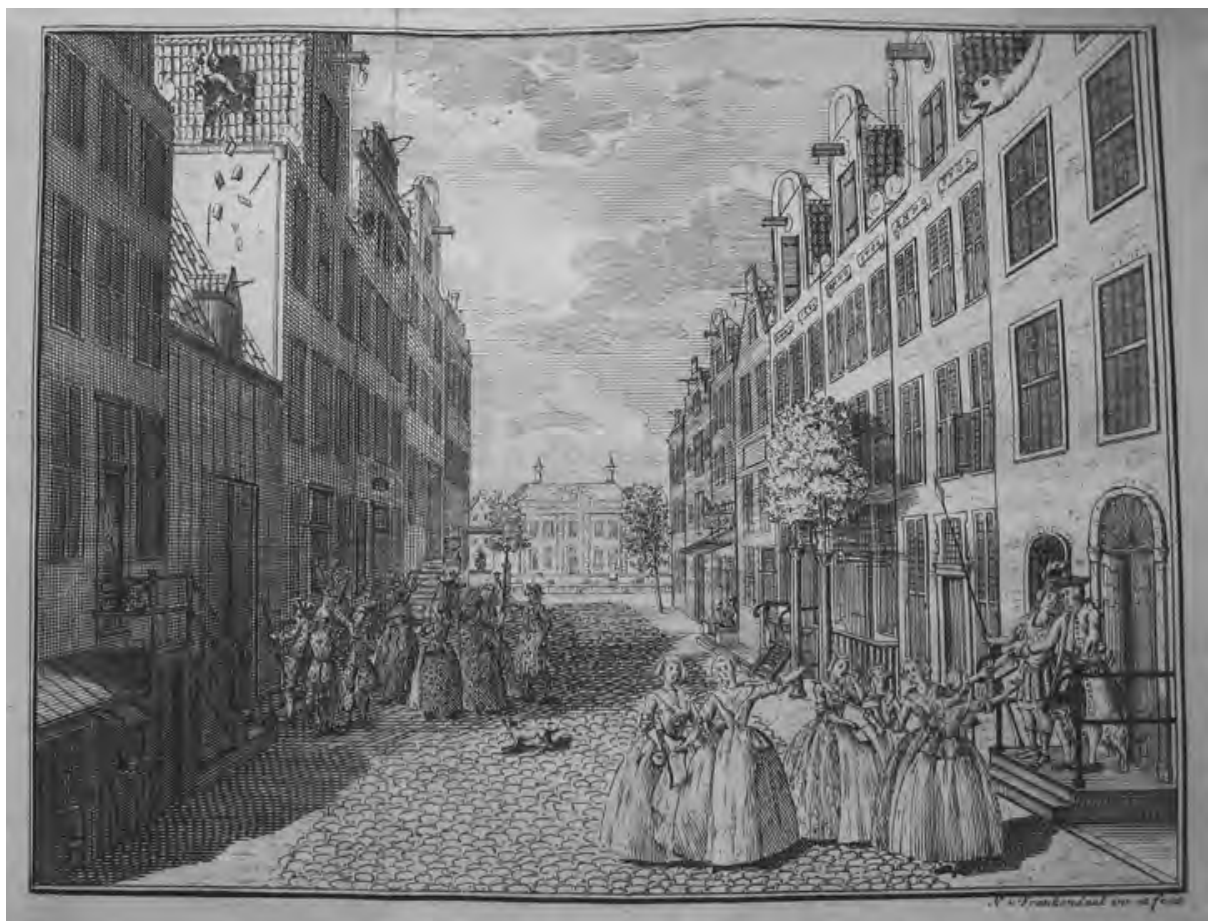

Illustration 9. Praatvaar selling his New Year gift to the Young Ladies, assisted by Wisdom (right) and escaping from his ennemies through the roof (left). Engraving by N. van Frankendaal from Hollandszen Praat-vaars Nieuwjaarsgift, Amsterdam: widow Jacobus van Egmont, c. 1745-50, facing fol. * $^{*}$. Amsterdam, Meertens Institute, B54.

\section{The concept of Apollo's gifts: inspiration and imitation}

The idea of choosing the Kermesse as a starting point for a songbook was not entirely new in 1740. In the preceding century there had been songbooks such as Koddige olipodrigo of nieuwe Kermiskost (Droll hotch-potch or new Kermesse food, presented to the Kermesse guests and farce-loving minds, 1655) ${ }^{39}$ and Uytertse hylickmaeckers, vol soetigheydt, ofte Amsterdamse kermiskoeck (Utrecht marriagebrookers [i.e. wedding cakes], full of sweet, or Amsterdam Kermesse cake, served for the invited Kermesse guests and skilful singers; after 1677)..$^{40}$ The latter book was intended for two groups of youngsters, one from Amsterdam and one from Utrecht, who visited the Kermesse in each others' cities. Our "Apollo" from The Hague probably did not know these seventeenthcentury songbooks, yet they show that the concept of a Kermesse songbook was quite possible. For the New Year gift Apollo may have had more examples: there were innumerable booklets and broadsheets with "Nieuwjaarsgiff" in their titles, although

\footnotetext{
${ }^{39}$ Koddige olipodrigo of nieuwe kermiskost, voorgesteld aen de kermisgasten en kluchtlievende geesten. Deel 1, Amsterdam: Evert Nieuwenhoff, 1655.

${ }^{40}$ Uytertse hylickmaeckers, vol soetigheydt, ofte Amsterdamse Kermiskoeck, opgedist voor de genoode Kermis gasten en aerdige sangers ende sangeressen, Amsterdam: Fam. Lootsman, after 1677.
} 
most such works had nothing to do with singing. ${ }^{41}$ Books entitled "St. Nicholas gift" or "Carnival gift" were much rarer. ${ }^{42}$

The idea of an Apollo's Kermesse gift inspired not only a series of Apollo's gifts, as we have seen, but also other songbooks, such as the previously mentioned Hollandszen Praat-vaars Nieuwjaarsgift, printed in Amsterdam but dedicated to the Utrecht girls ("Stichtze Jufferschap"). "Praatvaar" (i.e. Chatterbox), who also called himself "H. Overal” (H. Everywhere), was a journalist who published a weekly periodical, Den Hollandszen Praat-vaar (The Dutch Chatterbox). In his Dedication he explicitly mentions that Apollo's Kermesse gift and New Year gift were models for his own New Year gift, but he criticizes St. Nicholas gift as being "full of old rags and street songs" (which is in fact correct, as we will see later). An illustration that serves more or less as a title engraving shows Praatvaar in front of his house, selling his New Year gift to the young ladies, who are so eager to purchase it that they do not care about the money, as is stated in an explicatory poem (Illustration 9). A personification of Wisdom stands at his side. Clearly, the engraver, Nicolaes van Frankendaal, was inspired by the image of Apollo distributing his songs to the young. A curious detail is that on the other side of the street we see the same Praatvaar, now escaping through the roof of his house while being attacked by enemies driven by Jealousy.

Praatvaar stresses the importance of memorizing the songs. He promises that when the girls and their boyfriends know the new songs by heart he will publish a new songbook, and sooner if they send in new songs. It is possible that the promised new songbook became Praatvaars Vasten-avondsgift (Chatterbox's Carnival gift), published in Amsterdam by the same printer who had printed Praatvaar's New Year gift, the widow of Jacobus van Egmont. ${ }^{43}$

Other songbooks that may have been inspired by Apollo's (or Chatterbox's) New Year gift are Orangje Nieuwjaars gift (Orange New Year gift, 1748), which was also printed by the widow Van Egmont, with a second part from 1750, and the Princelycke Nieuw-jaars-gift, of Het Oranje hof in vreugde (Princely New Year gift, or The Orange court in joy), from about the same time. Chatterbox's sequence New Year - Carnival gift re-emerges in two songs, Nieuwejaars gift aan de Nederlandsche [...] juffers (New Year gift to the Dutch ladies, 1755, a plea against marriage between spouses of different religions), and Vasten-avond gift (Carnival gift), "being a chaste and farcical response to the answer against the New Year gift about mixed marriages".44

\footnotetext{
${ }^{41}$ An exception is the songbook Stootkant of Nieuwe-Jaars-gift, aan de Amstelsche jonkheidt (Bumper or New Year gift to the Amsterdam youth), Amsterdam: Jakob Vinkkel, 1655.

${ }^{42}$ E.g. St. Niklaes gift, bestaende in bevallijke kodderyen, aertige voorvallen, vreemde potsen, en verdichte vonden, Amsterdam: Johannes Jacott, 1647. Carnival gifts were e.g. Vasten-Avonts gift, aen den onbeschaemde paepsche leughendichter, het sotje vol van sonden, [1647]; Vasten-avonts-gift, aan den nieuw-opgerezene Amsteldamze Antekrist, 1648; Vasten avonds gift aen de heeren gecommitteerden van de Zwolsche classis, Leiden: A. Vryhart, 1756.

${ }^{43}$ The three copies mentioned in Short Title Catalogue of the Netherlands (STCN) are dated 'not before 1753'.

${ }^{44}$ Nieuwejaars gift aan de Nederlandsche [...] juffers, zynde een nieuw lied tegens de gespikkelde huwelyken, The Hague: Pieter van Os, 1755, and Vasten-avond gift, zynde een zeedige en boertige beantwoording op het antwoord tegens het nieuwejaarsgift op de gespikkelde huwelyken, The Hague: Hendrik Scheurleer, [1755].
} 


\section{The secret of Apollo's gifts}

All these imitations, whether direct or indirect, confirm that Apollo's gifts was a phenomenon. It is not clear whether this was the result primarily of the quality of the songs - they were not evidently better than or different from the songs in, for instance, Thirsis minnewit. But they were new, as is easily ascertained in the Dutch Song Database. The First and Second Kermesse gift and the New Year gift, the Hague nucleus of the complex, distinguish themselves in this respect from imitations such as the St. Nicholas gift and the Carnival gift, in which the majority of the songs seem to have been taken from other songbooks. ${ }^{45}$ On the other hand it is surprising to discover that most of the songs of the Kermesse gift and New Year gift were never included in subsequent songbooks, so one wonders whether the songs were really that popular. ${ }^{46}$

Another explanation may be that the attractive concept expressed in titles such as Apollo's Kermesse gift, implies a combination of three customs, namely giving songbooks to girlfriends, giving gifts at certain annual feasts, and singing at such feasts. The moments of publication seem to have been chosen very effectively: we know that some of the Gifts were advertised on dates connected with annual feasts, especially New Year. ${ }^{47}$ The conspicuous title engravings illustrating the concepts certainly would have contributed to their success. Other factors may have been the association with the Hague beau monde and the entertaining style of "Apollo", the life and soul of their parties - although this young man adopted what is surely the most obvious pseudonym imaginable for a leader of a company of singing ladies.

Although Apollo, being a gentleman, probably did not have a financial interest in the project, it was important for his social capital that the printer Van den Bergh made enough profit to publish another songbook. Apollo's sales strategy turned out to be quite successful if what is said about it in the New Year gift was true: in flattering the young ladies with an amusing dedication he had more or less forced their boyfriends to buy the books.

\section{Conclusion: Apollo's gifts in an urban context}

As a series of songbooks Apollo's gifts contributed to the soundscape of the early modern city. They remind us of the important function of informal public singing

\footnotetext{
${ }^{45}$ For instance, in the First Kermisse gift I could find only one song that was previously published ("Juffertje, ' $k$ bid eens segt, ta, la, la, \&c", p. 81, which can also be found in De groote nieuwe Hollandschen bootsgesel, Amsterdam: Abraham van der Putte, c. 1700). On the other hand, at least half of the St. Nicholas gift songs seem to be taken from earlier sources, and even more of the Carnival gift songs. Checked in the Dutch Song Database, 15 February 2011.

${ }^{46}$ Only about $15 \%$ of the First Kermesse gift songs turn out to be reprinted, e.g. in De nieuwe vermaaklyke gaare-keuken van de gekroonde A, Amsterdam: Johannes Kannewet, 1746/47, a collection of 248 songs that all start with the letter A.

${ }^{47}$ New Year's gifts were advertised on New Year's day by Jan van den Bergh (Leidsche Courant, 1 January 1742, the day of its first appearance) and the Rotterdam printer Hendrik Maronier ('s-Gravenhaagsche Courant, 1 January 1753; presumably the day of first appearance of the Maronier's Second New Year gift). Pieter Servaes advertised his Apollo's Vasten-avond-gift in the 's-Gravenhaagsche Courant of 26 February 1745, a few days before Shrove Tuesday which fell that year on 4 March. (Servaes had advertised this book also on 25 November 1744.)
} 
at annual feasts such as the Kermesse, New Year's, St. Nicholas and Carnival. The entire population participated in such celebrations, including the elite and the middle classes who imitated the elite, as can be deduced from the songbooks. Apollo's gifts also reminds us that these feasts were not merely folklore in the countryside but also a part of urban daily life.

Unlike typical local songbooks Apollo's gifts was not limited to one city. In early modern Dutch culture Amsterdam was often the centre of this sort of publication series, but that city played a subordinate role in the Apollo complex. In this case, The Hague was the starting point. The songbooks transcended the city boundaries in several ways. First, the local youth sometimes visited Kermesses in other cities, as had "Apollo", the initiator of the series, when he heard girls singing "his" songs on the Amsterdam Kermesse. Second, publishers tried to sell their songbooks in other cities as well, as did the Hague publisher Van den Bergh when he advertised his New Year's gift in Leiden. Third, printers from other cities published pirate editions of Apollo's gifts. Thus the songs came to be distributed among several Dutch cities, especially in the province of Holland.

Typical for Apollo's gifts is the fashionable atmosphere that is conveyed by the title engravings, the preliminary materials and the relatively high prices. This emphasizes the work's Hague origins. The Hague was a fashionable city and is still known as the "court city" - although in the songbooks we could find no direct references to the Stadtholder's court. 


\section{Appendix: Overview of editions of Apollo's gifts}

This overview is based on the comprehensive systematic bibliography of BosGRAAF, Apollo's giften, extended with some new information from STCN (Short Title Catalogue of the Netherlands).

Apollo's Kermis-gift (Apollo's Kermesse gift)

Eerste deel (First part)

1740 The Hague: Jan van den Bergh

1743 The Hague: Jan van den Bergh - 3 editions

1745 Hoorn: Egidius van Ophem

17XX Dordrecht: Hendrik Walpot (active 1727-1759) - 2 editions

17XX Amsterdam: Abraham Cornelis (active 1756-1780)

Idem, Tweede deel (Second part)

1743 The Hague: Jan van den Bergh

1745 Hoorn: Egidius van Ophem

17XX Dordrecht: Hendrik Walpot - 2 editions

17XX Amsterdam: Abraham Cornelis

Idem, Derde deel (Third part)

1746 Amsterdam: Jacobus Friesewyck - 2 editions

Apollo's St. Nicolaas gift (Apollo's St. Nicholas gift)

[1741] Leiden: Johannes van Kerckhem

Apollo's Nieuwe-Jaers-gift (Apollo's New Year gift)

1742 The Hague: Jan van den Bergh

1745 The Hague: Jan van den Bergh

1745 Dordrecht: Hendrik Walpot - 2 editions

1750 Dordrecht: Hendrik Walpot

Idem, Tweede deel (Second part)

1753 Rotterdam: Hendrik Maronier

Apollo's Vastenavond-gift (Apollo's Carnival gift)

1745 The Hague: Pieter Servaas

17XX Dordrecht: Hendrik Walpot - 2 editions 